\title{
EVALUATION OF A DUPLICATOR LATHE WITH HYDROSTATIC BEARING SLIDES AND AN ELECTROHYDRAULIC CONTROL SYSTEM (U)
} \\ J. B. Richards}

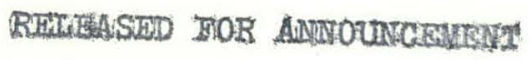

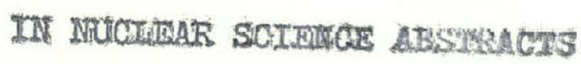

\section{UNION CARBIDE CORPORATION NUCLEAR DIVISION OAK RIDGE Y-12 PLANT}

operated for the ATOMIC ENERGY COMMISSION under U. S. GOVERNMENT Contract W-7405 eng 26 


\section{DISCLAIMER}

This report was prepared as an account of work sponsored by an agency of the United States Government. Neither the United States Government nor any agency Thereof, nor any of their employees, makes any warranty, express or implied, or assumes any legal liability or responsibility for the accuracy, completeness, or usefulness of any information, apparatus, product, or process disclosed, or represents that its use would not infringe privately owned rights. Reference herein to any specific commercial product, process, or service by trade name, trademark, manufacturer, or otherwise does not necessarily constitute or imply its endorsement, recommendation, or favoring by the United States Government or any agency thereof. The views and opinions of authors expressed herein do not necessarily state or reflect those of the United States Government or any agency thereof. 


\section{DISCLAIMER}

Portions of this document may be illegible in electronic image products. Images are produced from the best available original document. 
Printed in USA. Price $\$ 2.00$. Available from the Clearinghouse for Federal

Scientific and Technical Information, National Bureau of Standards,

U.S. Department of Commerce, Springfield, Virginia

\section{LEGAL NOTICE}

This report was prepared as an account of Government sponsored work. Neither the United States, nor the Commission, nor any person acting on behalf of the Commission:

A. Makes any warranty or representation, expressed or implied, with respect to the accuracy, completeness, or usefulness of the information contained in this report, or that the use of any information, apparatus, method, or process disclosed in this report may not infringe privately owned rights; or

B. Assumes any liabilities with respect to the use of, or for damages resulting from the use of any information, apparatus, method, or process disclosed in this report.

As used in the above, "person acting on behalf of the Commission" includes any employee or contractor of the Commission, or employee of such contractor, to the extent that such employee or contractor of the Commission, or employee of such contractor prepares, disseminates, or provides access to, any information pursuant to his employment or contract with the Commission, or his employment with such contractor. 
Date Issued: December 29, 1965

Report Number. $Y-1498$

Engineering and Equipment

TIO-4500 (46th Edition)

\section{UNIÓN CARBIDE CORPORATION \\ Nuclear Division}

$$
\text { Y-12 PLANT }
$$

Contract W-7405-eng-26

With the US Atomic Energy Commission

EVALUATION OF A DUPLICATOR LATHE WITH HYDROSTATIC BEARING SLIDES AND AN ELECTRO'HYDRAULIC CONTROL SYSTEM (U)

J. B. Richards

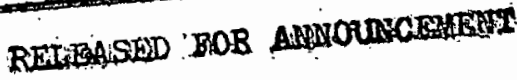

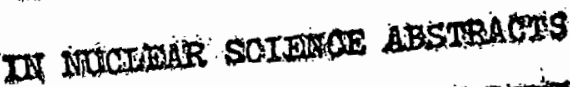

Oak Ridge, Tennessee

August 26, 1965 
Report Number ${ }_{Y-1498}$

Engineering and Equipment TID-4500 (46th Edition)

Distribution:

Ackerson, R. D.

(AFSC)

Lewis, F. O.

(ORGDP)

Bailey, E. W.

Little, J. C.

Ballenger, H. F.

McLendon, J. D.

Bernander, N. K.

Mitchel, G.W.

Burkhart, L. E.

Patton, F. S.

Center, C. E.

(ORGDP)

Perry, A. E.

Christman, A. M.

Rader, D. H.

Cowen, D. D.

(ORNL)

Richards, J. B.

Ebert, J: W.

Rucker, R. S.

Evans, G.W.

Schede, R. W.

Fortenbery, M. J.

Smith, H. F., Jr.

Foulk, D. L.

Sommerfeld, K. W.

Fuis, F.

Thomas, F. W.

Gritzner, V. B.

Trotter, T. C.

Groothuis, S. E.

Waters, J. L.

Harding, J. E.

Whitson, W. K.

Harwell, W. L.

(ORGDP)(5)

Whitten, L. G.

Hemphill, L. F.

Williams, J. L.

Hensley, C. E.

Winkel, R. A.

(Paducah)

Huber, A. P.

(ORGDP)

Yaggi, W. J.

Jennings, D. A .

Zurcher, E.

Kahl, K. G.

Y -12 Central Files

(5)।

Keller, C. A.

$(A E C-O R O)(4)$

Y-12 Central Files

$(Y-12 R C)$

In addition, this report is distributed in accordance with the category Engineering and Equipment, as given in the "USAEC Standard Distribution Lists for Unclassified Scientific and Technical Reports", TID-4500 (46th Edition), October 1, 1965. 


\section{ABSTRACT}

An American 25-inch duplicator lathe was modified with hydrostatic slides and an electrohydraulic control system. Test procedures were developed and resulis were obtained that compare its performance with a conventional machine. 


\section{THIS PAGE \\ WAS INTENTIONALLY \\ LEFT BLANK}


CONTENTS

INTRODUCTION .......................... 7

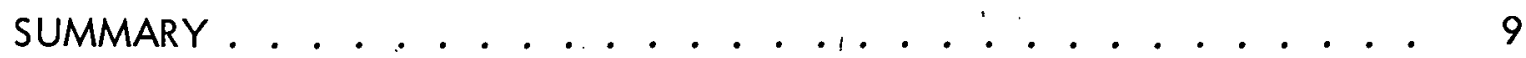

EVALUATION OF THE BEARING AND SLIDES ........... 11

Principles and Application . . . . . . . . . . . . . . . . 11

Test Results. . . . . . . . . . . . . . . . . . . . . . . . . . . 12

Collimation Tests . . . . . . . . . . . . . . . . . . . . . 12

Slide-Stiffness Tests . . . . . . . . . . . . . . . . . 12

Twin-Disc Tests . . . . . . . . . . . . . . . . . . . 15

Machining Tests . . . . . . . . . . . . . . . 20

Control-System Tests . . . . . . . . . . . . . . . . . 20

Velocity-Error Tests . . . . . . . . . . . . . . . . . 20

Frequency-Response Tests . . . . . . . . . . . . 23

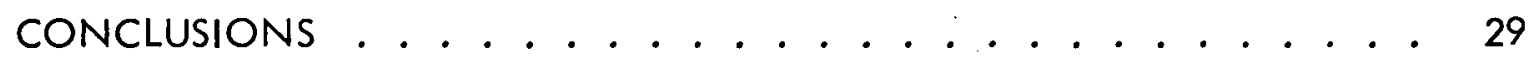




\section{THIS PAGE}

\section{WAS INTENTIONALILY \\ LEFT BLANK}




\section{INTRODUCTION}

New developments which may improve the accuracy of machine tools are constantly being evaluated. Two such developments are hydrostatic bearings and electrohydraulic control systems, both of which have been incorporated in the modification of a very accurate duplicator lathe. This study was made to determine the feasibility of using these two elements to further improve the existing machines.

One of the more serious problems associated with duplicator lathes is the wear and subsequent lack of straightness in the cross slide and 45-degree slide. To improve the performance and life of these elements, the conventional 45-degree slide was replaced with a slide which is completely supported by hydrostatic bearings. Also, a hydrostatic bearing cross slide was installed in conjunction with the conventional cross slide. Because there is no metal-to-metal contact in hydrostatic bearings, the problem of wear should be eliminated and much straighter slides should be obtained.

The hydraulic control system now being used is operating satisfactorily, but any improvement in the system would be beneficial to the performance of the machine. For this reason, an electrohydraulic control system, similar to the control systems now being used on very accurate tape-controlled machine tools, was tested. 


\section{THIS PAGE WAS INTENTIONALLY LEFT BLANK}




\section{SUMMARY}

Tests have been conducted to evaluate the characteristics of a duplicator lathe equipped with hydrostatic bearing slides and an electrohydraulic control system. These characteristics were compared with those demonstrated by the same machine before the modifications were made.

To evaluate the slides independently of the control system, slide straightness and stiffness were measured. Only slight improvement in the slide straightness was realized by using the hydrostatic bearings, and the stiffness of the hydrostatic slides was much less than that of the conventional slides. This lack of stiffness resulted from an excessive deflection of the bearing housing and not from the hydrostatic bearing pads. By using a more rigid bearing housing, a much higher stiffness could be obtained.

Performance of the system containing both the slides and the control system was investigated by means of twin-disc tests, machining tests, and frequency-response tests. A significant improvement was realized in the twin-disc check of the modified system, but this improvement was not apparent in the machining tests. 'This difference is believed to be due to the deflection of the bearing housing. The frequency response of the electrohydraulic system was slightly less than the response of the hydraulic system. 


\section{THIS PAGE}

\section{WAS INTENTIONALLY \\ LEFT BLANK}




\section{EVALUATION OF THE BEARING AND SLIDES}

\section{PRINCIPLES AND APPLICATION}

A hydrostatic bearing is simply two surfaces completely separated by a thin fluid film which is supplied under pressure. Since the two bearing surfaces are completely separated, there is no friction as such, but merely a slight force opposing the relative motion of the surfaces due to the viscous properties of the fluid. Advantages of bearings of this type are: (1) very low friction, and (2) freedom from wear.

In this application, hydrostatic bearings are used in the 45-degree slide and in the support for the conventional cross slide. In the 45-degree slide, hydrostatic bearings were used to support a square boring bar on all four sides. As seen in Figure 1, this square bar has a round section which enables it to be used as a combination slide and hydraulic actuator. This actuator is a necessary part of the servo control system. The hydrostatic cross slide (Figure 2) is simply a conventional slide with hydrostatic bearing pads.

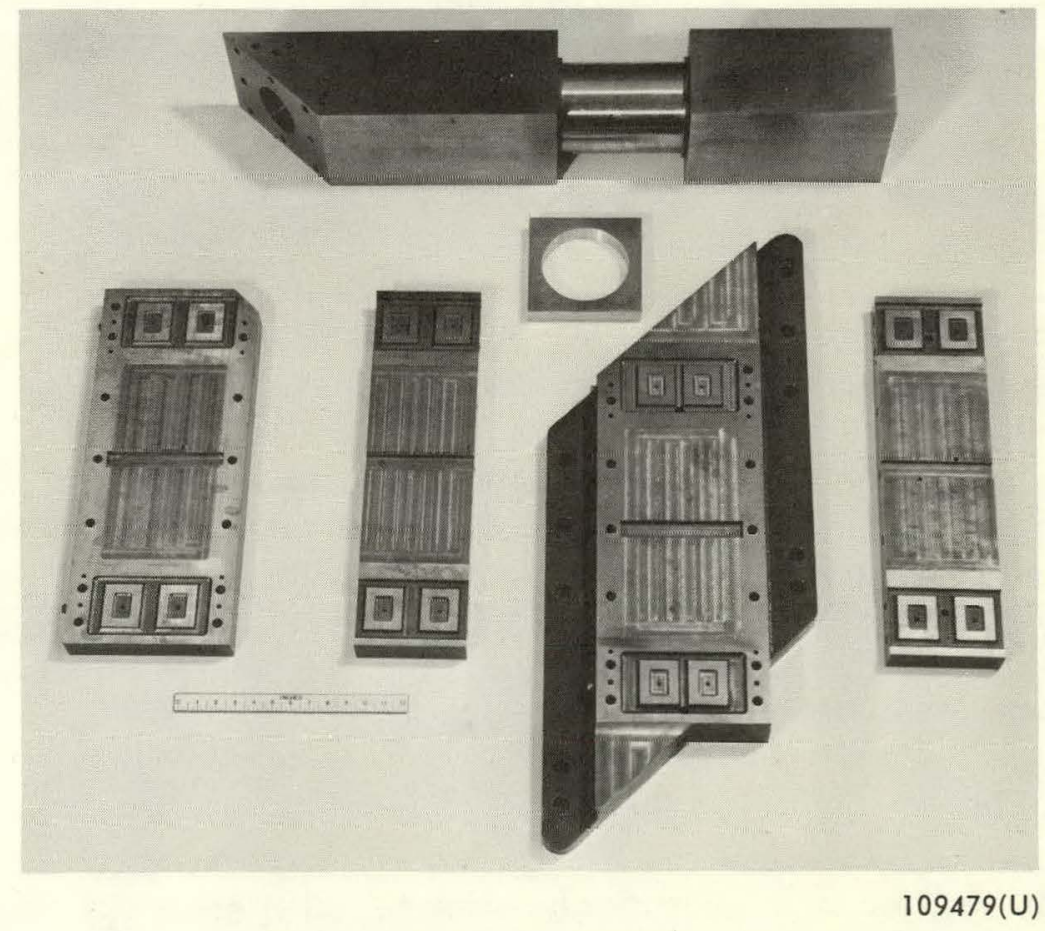

Figure 1. COMPONENTS OF THE HYDROSTATIC 45-DEGREE SLIDE. 


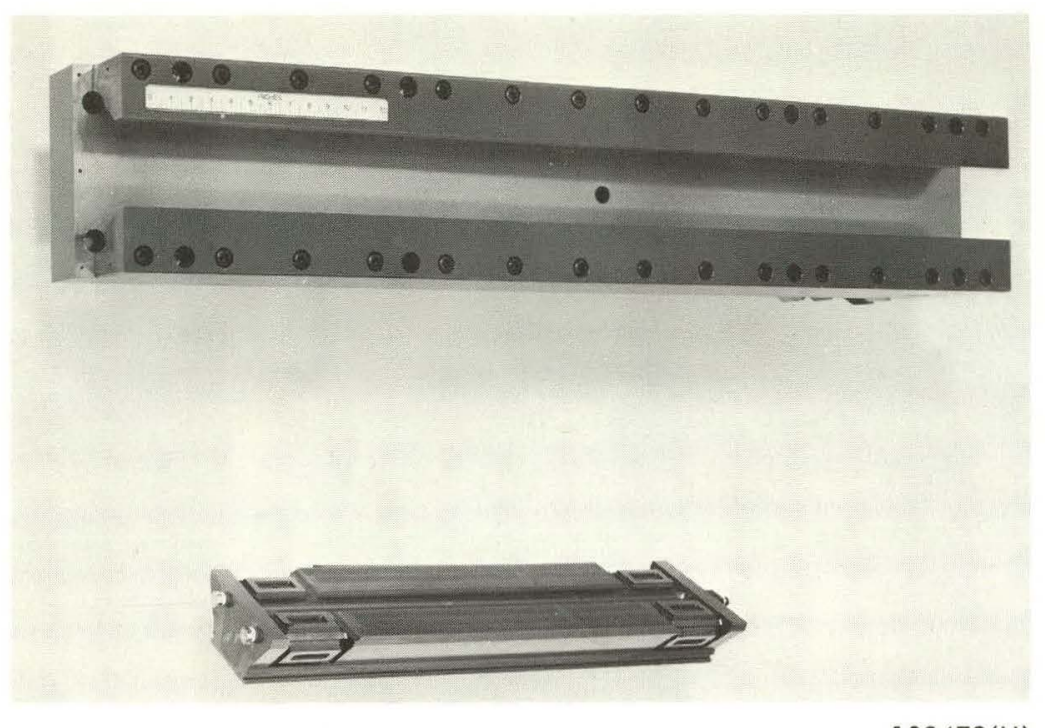

$109478(U)$

Figure 2. COMPONENTS OF THE HYDROSTATIC CROSS SLIDE.

\section{TEST RESULTS}

\section{Collimation Tests}

To compare the accuracy of movement of the conventional slides and the hydrostatic bearing slides, autocollimator tests were conducted using an automatic autocollimator capable of detecting angular changes of 0.2 second.

Since the collimator only measures the change in angle of a slide as it moves, an actual analysis of the tool-path accuracy cannot be made from this test. Thus, this test was used merely to compare the two types of slides.

Figures 3 and 4 show that no significant improvement was realized from installing the hydrostatic bearings on the 45-degree slide. On the hydrostatic cross slide (conventional cross-slide combination), the yaw (horizontal deviation) was 2 seconds compared to 14 seconds for the conventional cross slide alone (Figure 5). Figure 6 indicates that the addition of the hydrostatic cross slide caused an increase in pitch (vertical deviation) due to a large overhanging load.

Slide-Stiffness Tests

Stiffness can be defined as the ability of a slide to resist forces applied perpendicular to the axis of movement. In order for a cutting tool to accurately follow a prescribed tool path when subjected to cutting forces, the elements supporting the tool must be as rigid as possible. On this machine, the slides are an integral part of this support. 


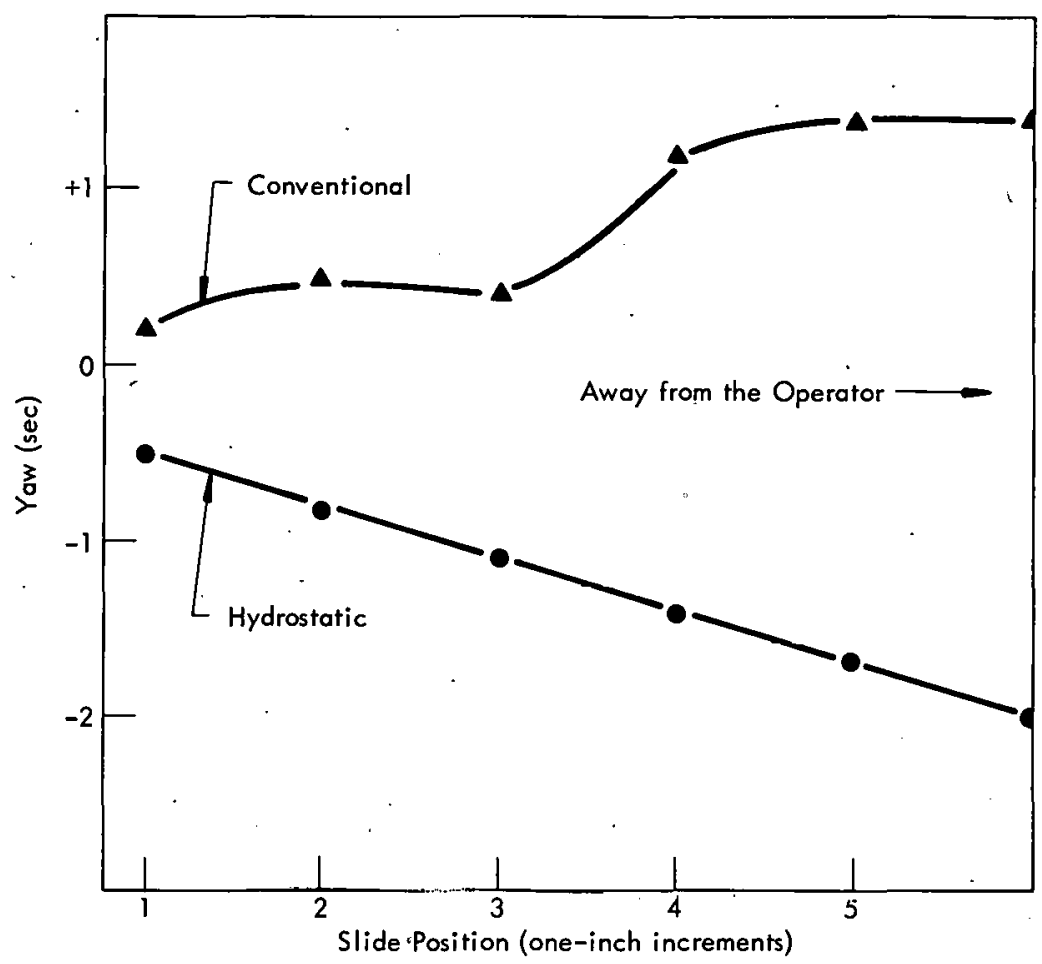

Figure 3. YAW OF A HYDROSTATIC SLIDE AND A CONVENTIONAL SLIDE AS FUNCTIONS OF THE SLIDE POSITION.

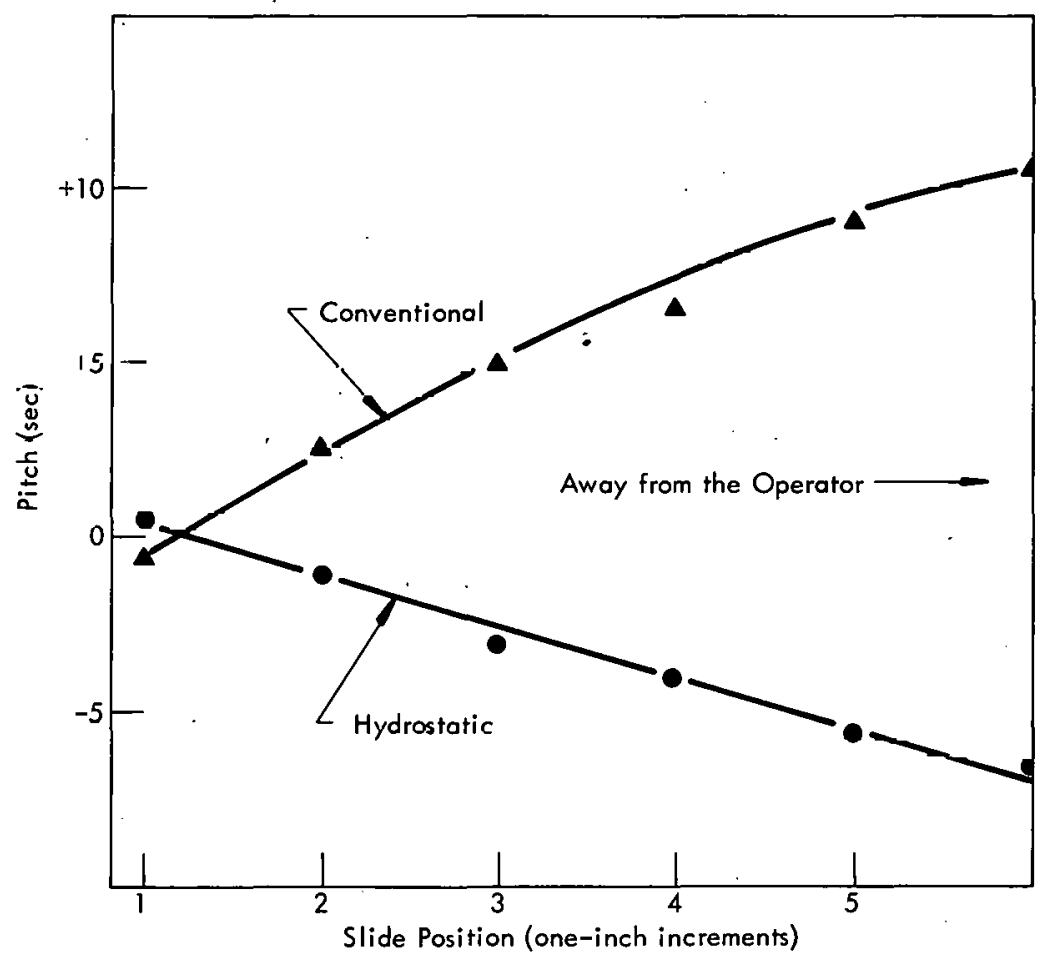

FIgurt 4. PITCH OF ^ HYDROSTATIC SLIDE AND A CONVENTIONAL SLIDE AS FUNCTIUNS UF THE SLIDE FOSITION. 


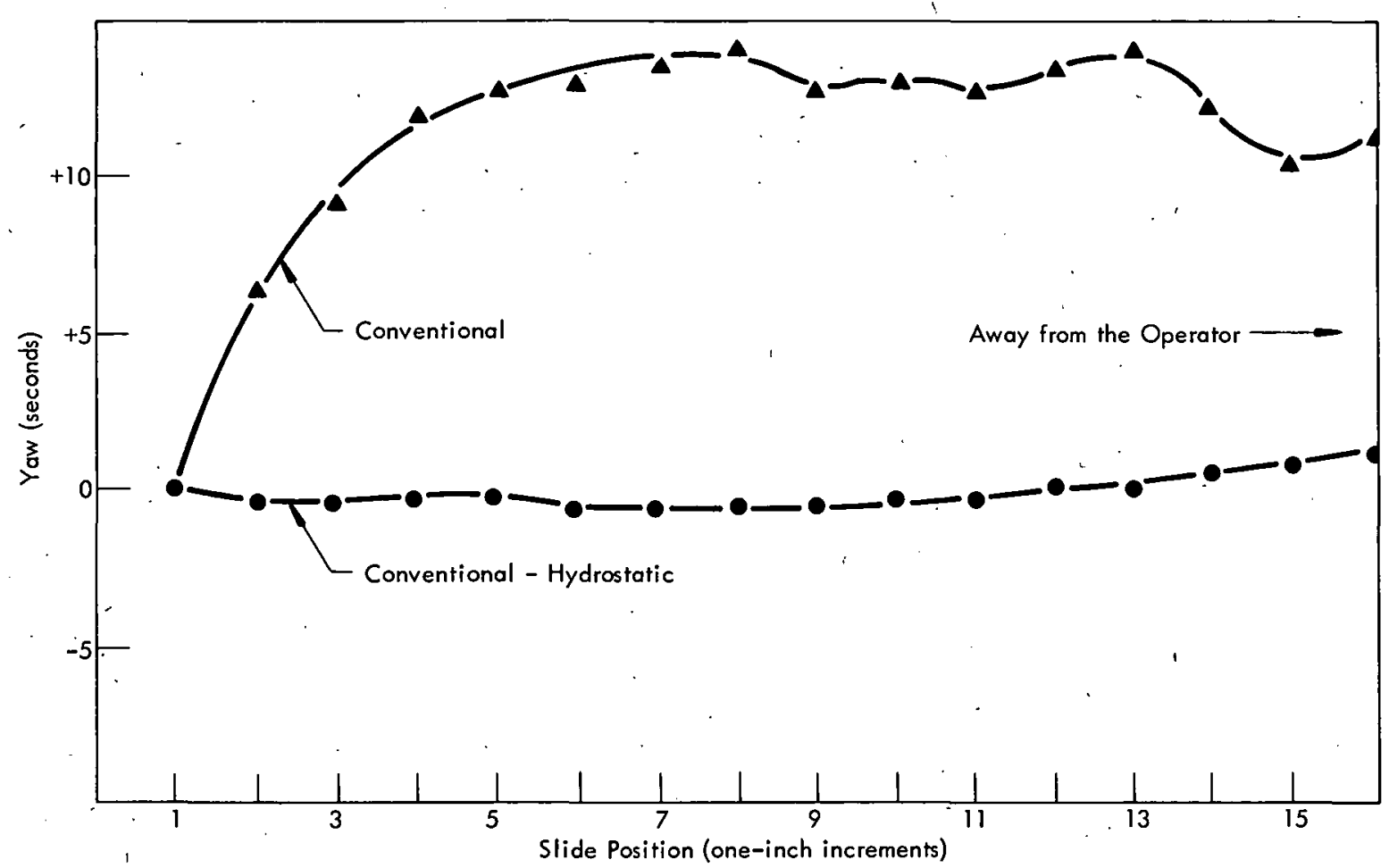

Figure 5. YAW OF A CONVENTIONAL SLIDE AND A CONVENTIONAL-HYDROSTATIC SLIDE COMBI. NATION AS FUNCTIONS OF THE SLIDE POSITION.

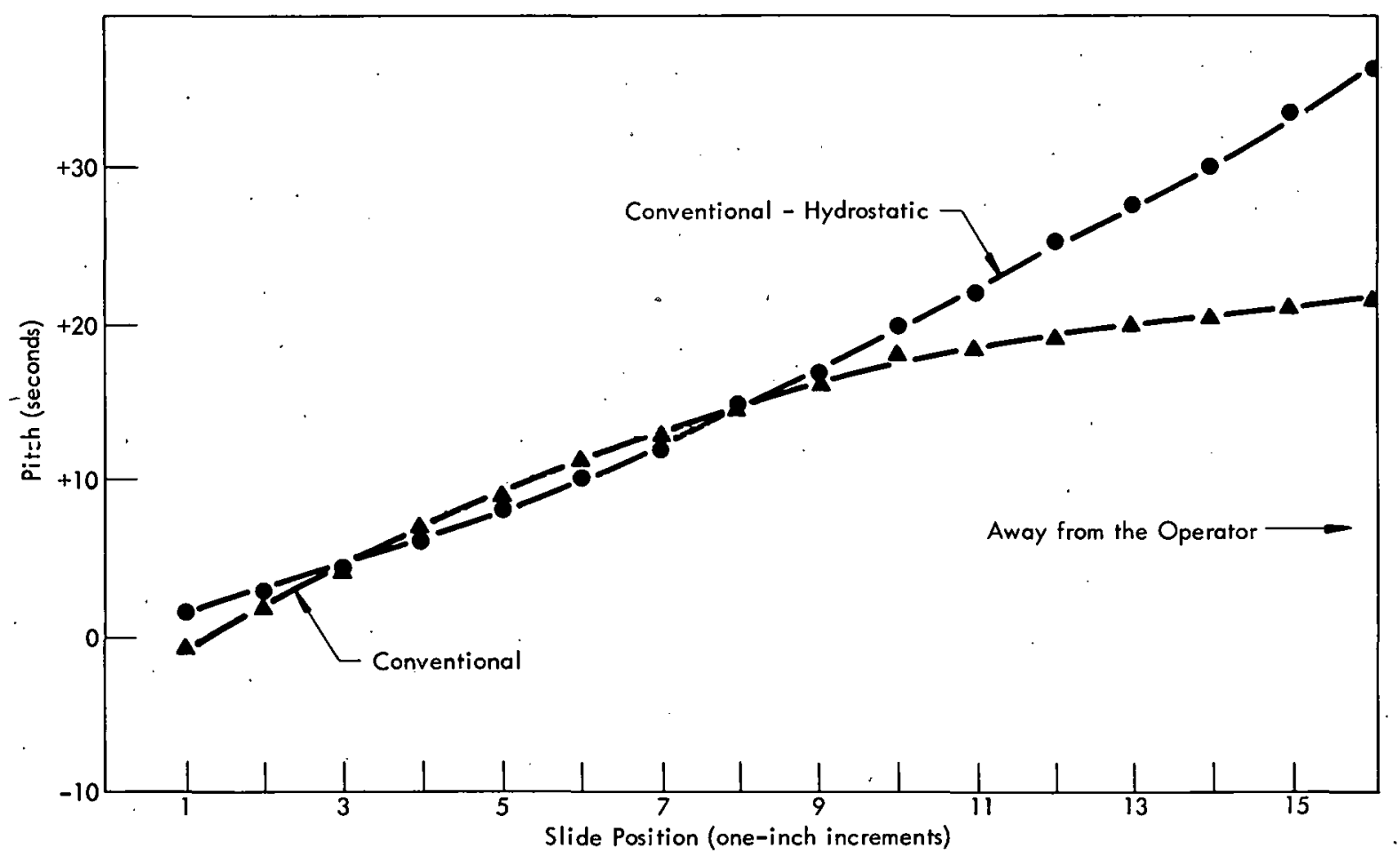

Figure 6. PITCH OF A CONVENTIONAL SLIDE AND A CONVENTIONAL.HYDROSTATIC SLIDE COMBINATION AS FUNCTIONS OF THE SLIDE POSITION. 
For a conventional slide, stiffness depends on the rigidity of the structural components of the slide as well as the clearance and oil film between the mating surfaces. For a hydrostatic bearing slide, the stiffness also depends on structural rigidity as well as such characteristics of the hydrostatic system as film thickness, pad pressure, pump pressure, and pad size.

Stiffness was measured on both the conventional slides and the hydrostatic slides by applying a load to the slide and measuring the resulting deflection. Figures 7 and 8 show how the loads were applied and Figures 9 through 12 show the results of the load application. Although loads of up to 800 pounds were used, loads of less than 100 pounds are more representative of normal cutting forces.

It will be noticed on Figures 9 and 10 that, for a load of 100 pounds, the horizontal deflection of the conventional 45-degree slide was less than 25 microinches compared to 250 microinches for the hydrostatic slide. The calculated stiffness for the hydrostatic slide was 70 microinehes for a 100-pound load.

Investigations revealed that the high deflection of the hydrostatic slide was caused by a low pad pressure $(50 \mathrm{psi})$ instead of the design pressure $(350 \mathrm{psi})$. To remedy this, the orifices between the pump and the pad were enlarged which would theoretically increase the oil flow and the pad pressure, assuming the film thickness remained constant. Subsequent tests revealed that the film thickness was actually increasing with no pad pressure increase due to the deflection of the bearing housing. To verify these observations, the pressures in the vertical pads were measured and found to be 350 psi-the design pressure. Vertical stiffness was measured and found to be 0.7 microinch per pound-the design stiffness. Because of the housing construction, the top and bottom sections were more rigid and the design pressures were achieved without housing deflection.

Stiffness of the conventional cross slide and of the combination conventional-hydrostatic cross slide was not measured independently, but was measured combined with the 45-degree slide. Stiffness of the 45-degree slide relative to the carriage was measured. This measurement included the 45-degree slide stiffness, the cross slide stiffness, and the rigidity of the slide components (Figures 11 and 12). For a 100pound load, the 45-degree slide moved horizontally a maximum of 350 microinches with the hydrostatic bearing slides and 25 microinches with the conventional slides. Here, again, the major contributing factor was the deflection of the bearing housing.

\section{Twin-Disc Tests}

Twin-disc checks ore used to determine the performance of the slides and the control system of a duplicator lathe under operating conditions. To perform this test, two matched circular templates are placed on the machine - one on the template stand and one in front of the spindle where the workpiece would normally be located, as shown in Figure 13. With the slides and control system operating, the system is controlled from one template and the tool path deviation is measured from the second template. 


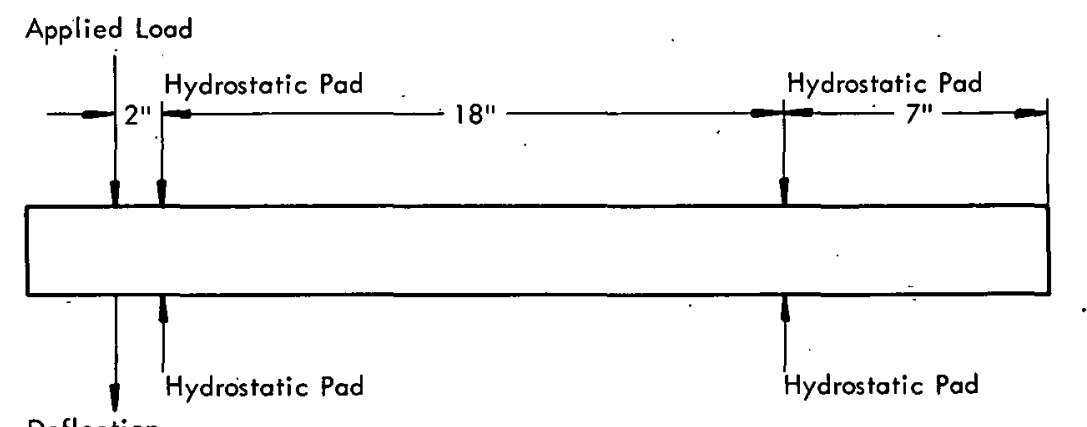

(a) Slide Out

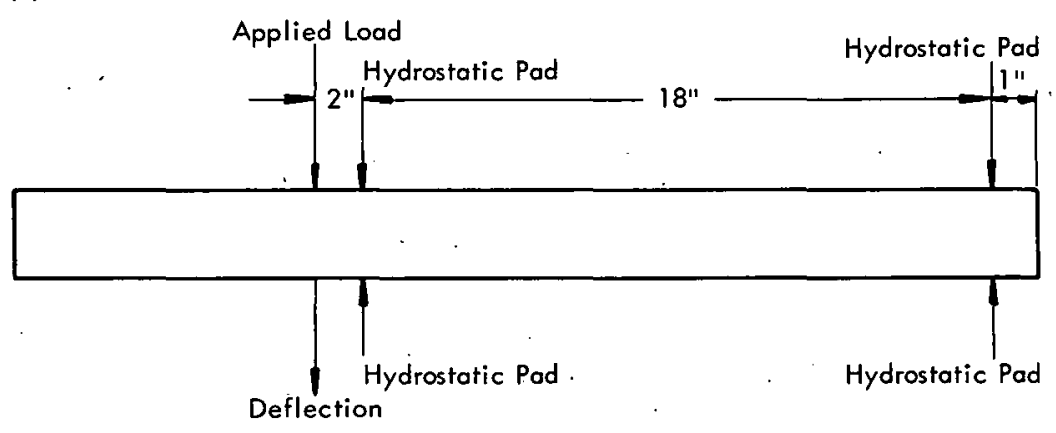

(b) Slide In

Figure 7. LOAD APPLICATION FOR THE HYDROSTATIC 45-DEGREE SLIDE.

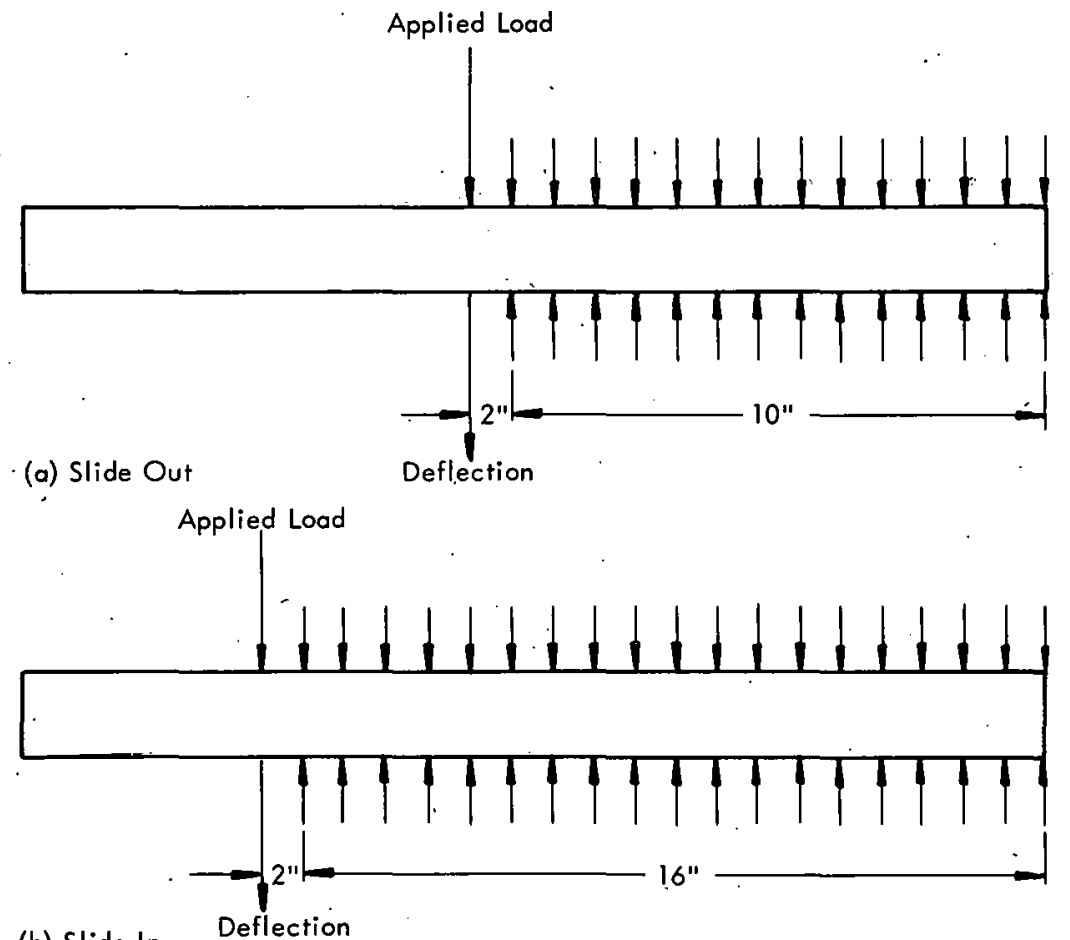

(b) Slide In

Figure 8. LOAD APPLICATION FOR THE CONVENTIONAL 45. DEGREE SLIDE. 


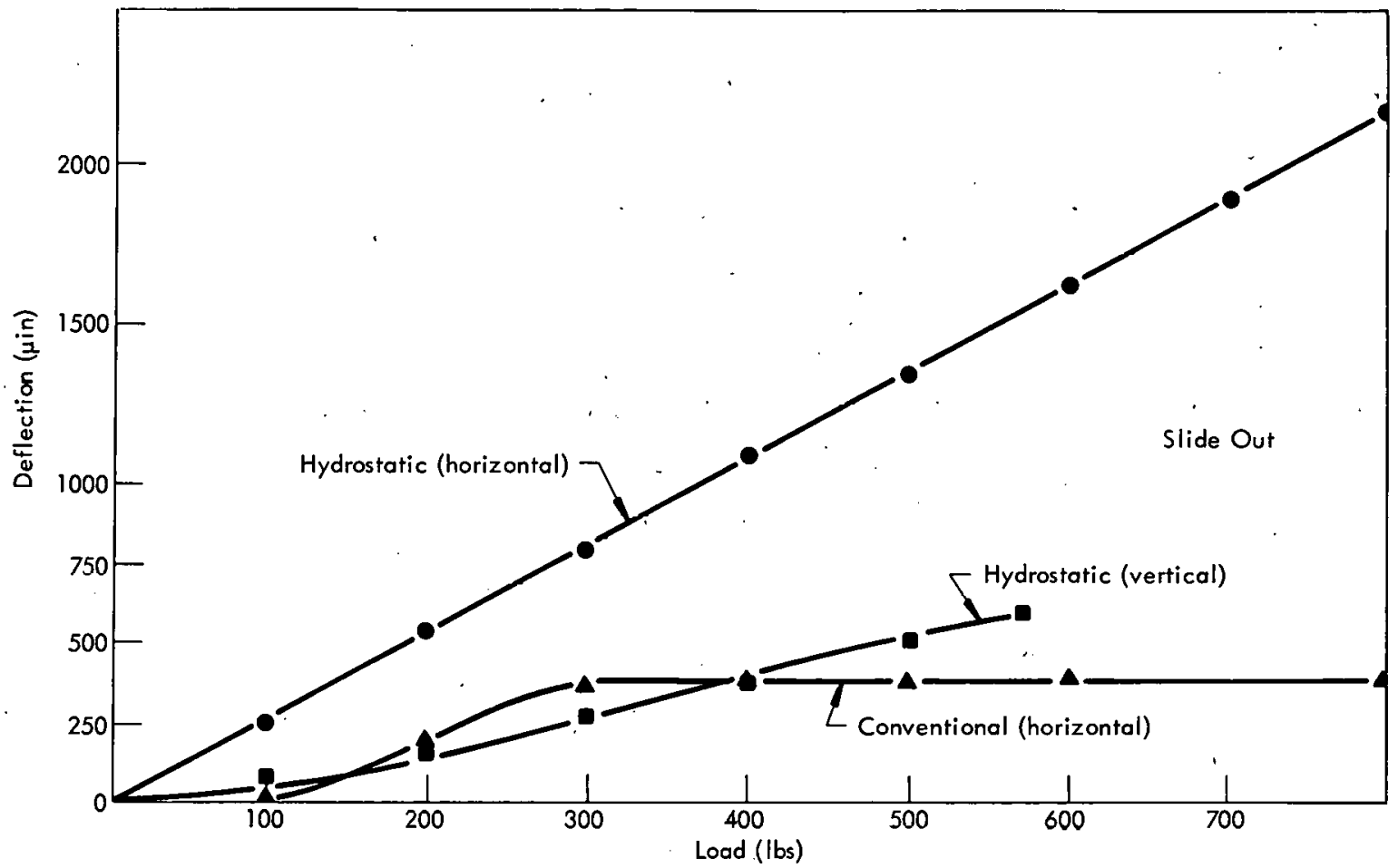

Figure 9. DEFLECTIONS OF A CONVENTIONAL SLIDE AND A HYDROSTATIC SLIDE AS FUNCTIONS OF THE LOAD. (Deflections Meosured Relative to the Slide Housing; Slide Out)

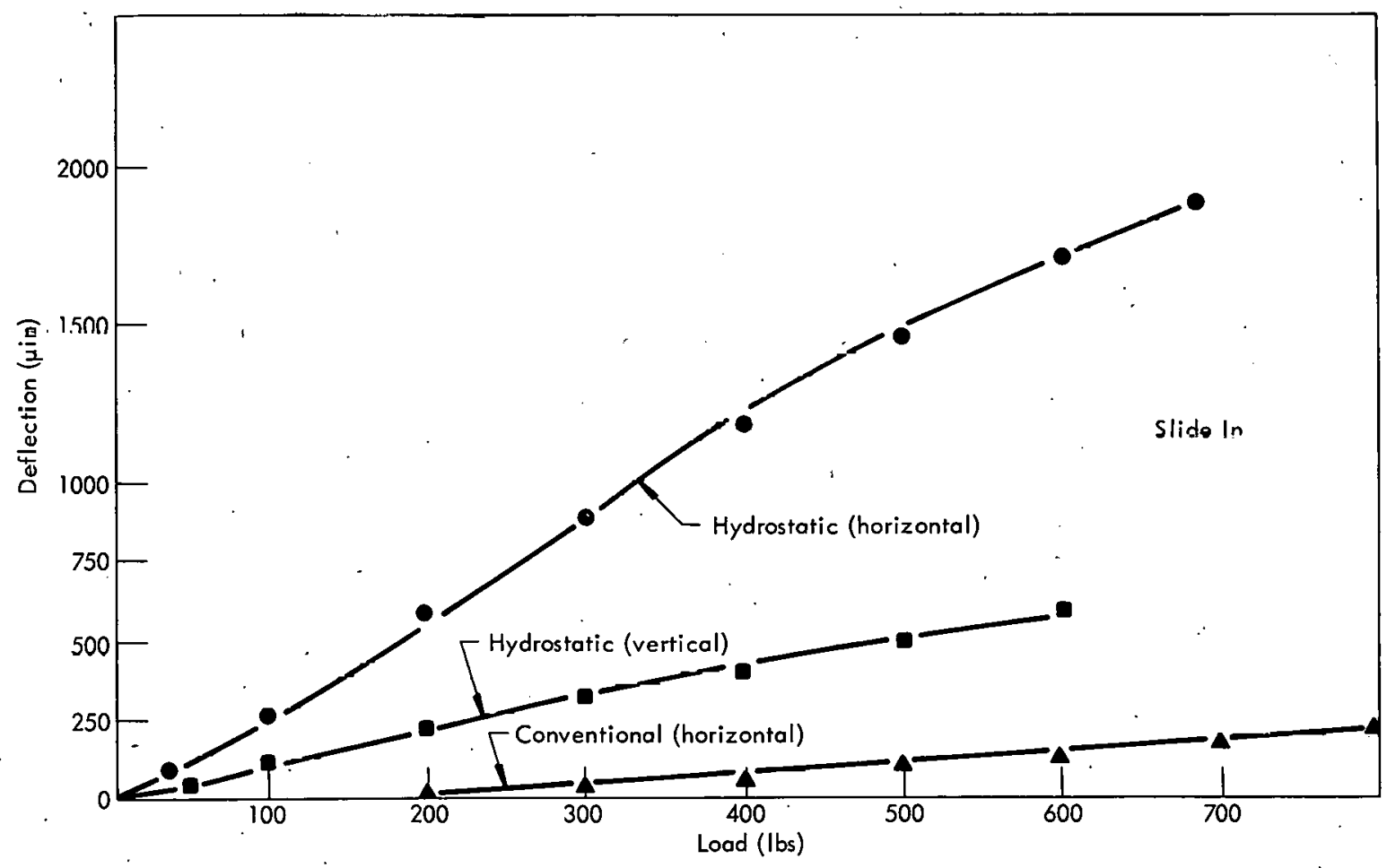

Figure 10. DEFLECTIONS OF A CONVENTIONAL SLIDE AND A HYDROSTATIC SLIDE AS FUNCTIONS OF THE LOAD. (Deflections Measured Relative to the Slide Housing; Slide In) 


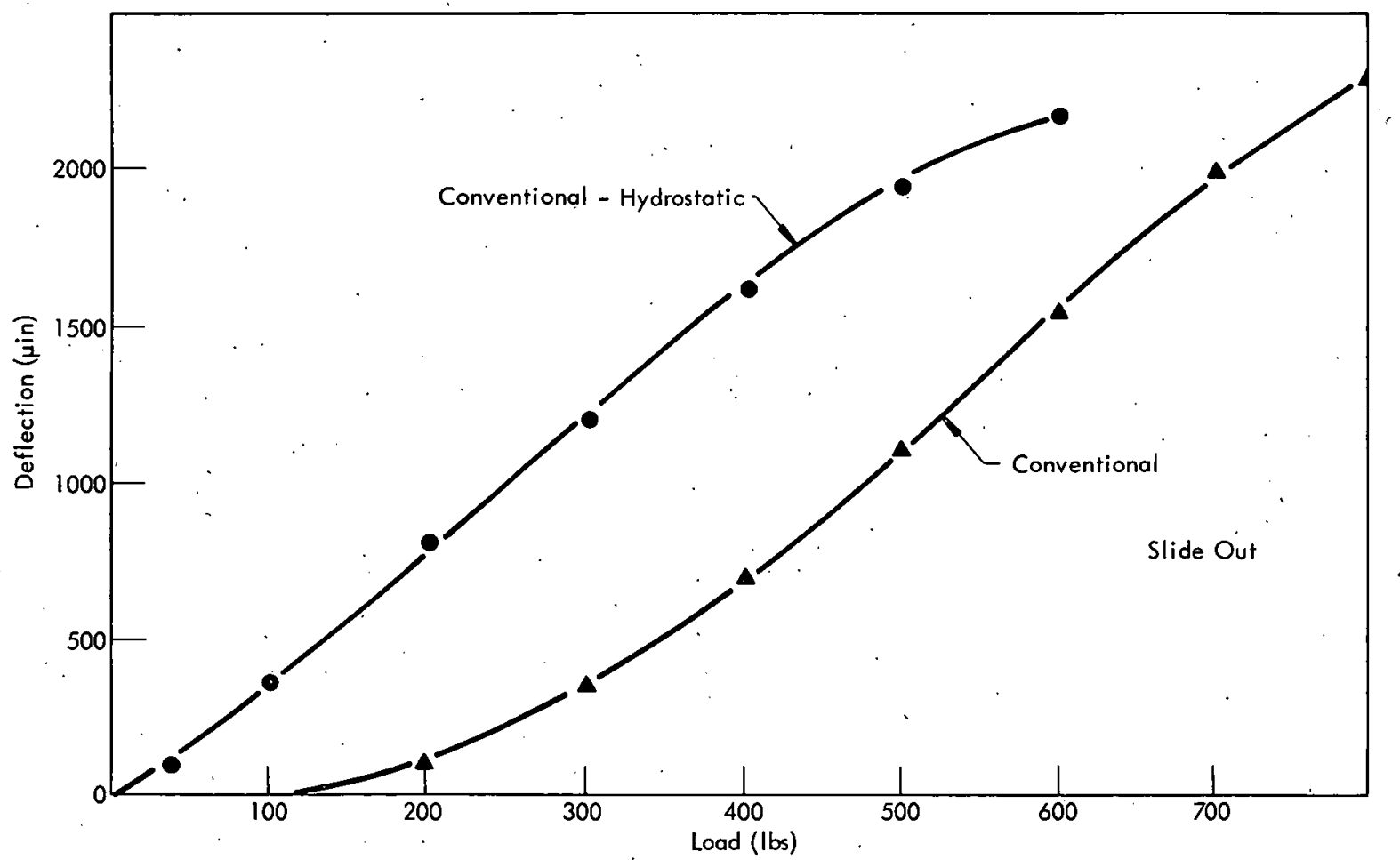

Figure 11. DEFLECTIONS OF A CONVENTIONAL SLIDE AND A CONVENTIONAL-HYDROSTATIC SLIDE COMBINATION AS FUNCTIONS OF THE LOAD. (Deflections Measured Relative to the Carriage; Slide Out)

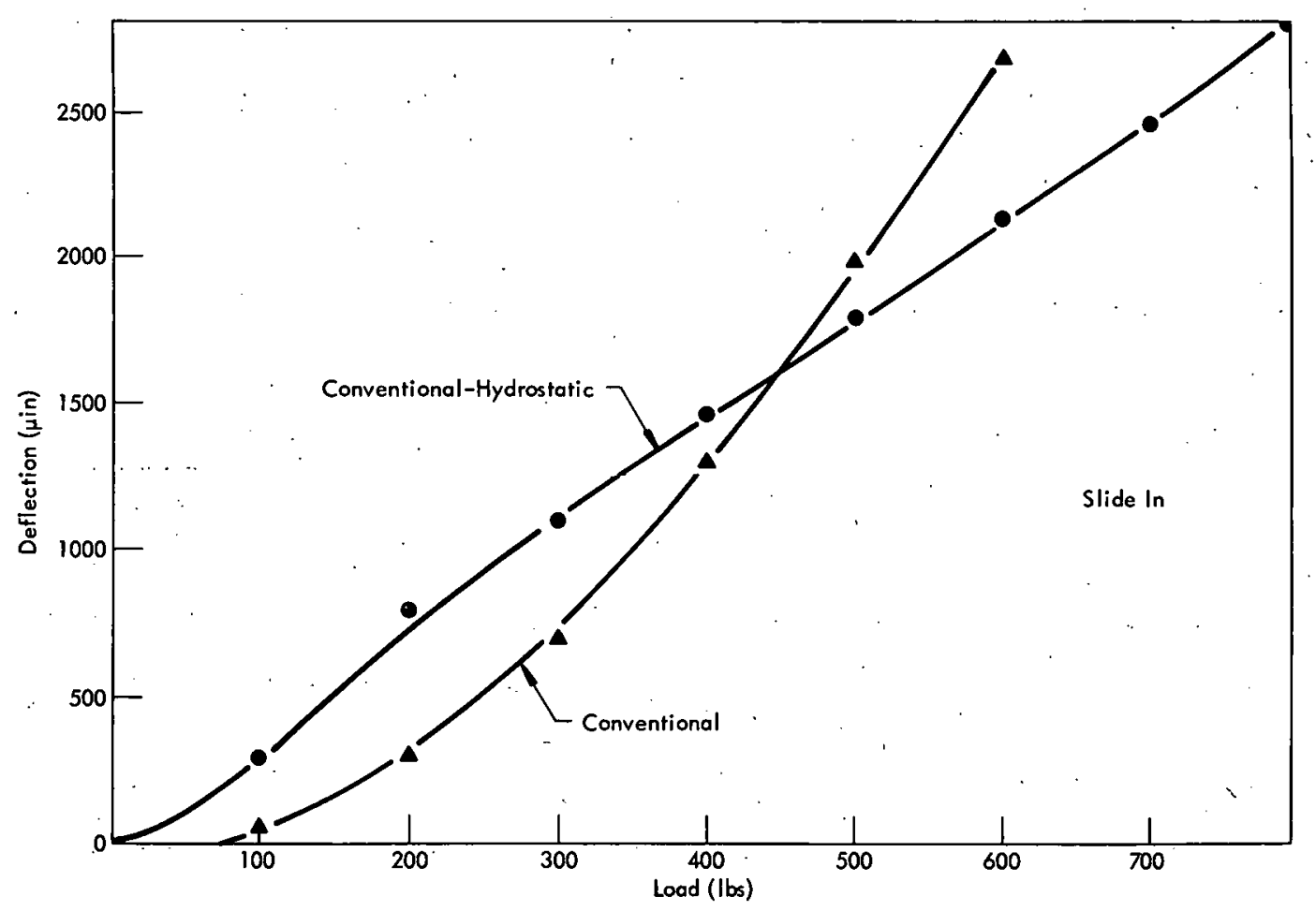

Figure.12. DEFLECTIONS OF A CONVENTIONAL SLIDE AND A CONVENTIONAL.HYDROSTATIC SLIDE COMBINATION AS FUNCTIONS OF THE LOAD. (Deflections Measured Relative to the Carriage; Slide In) 


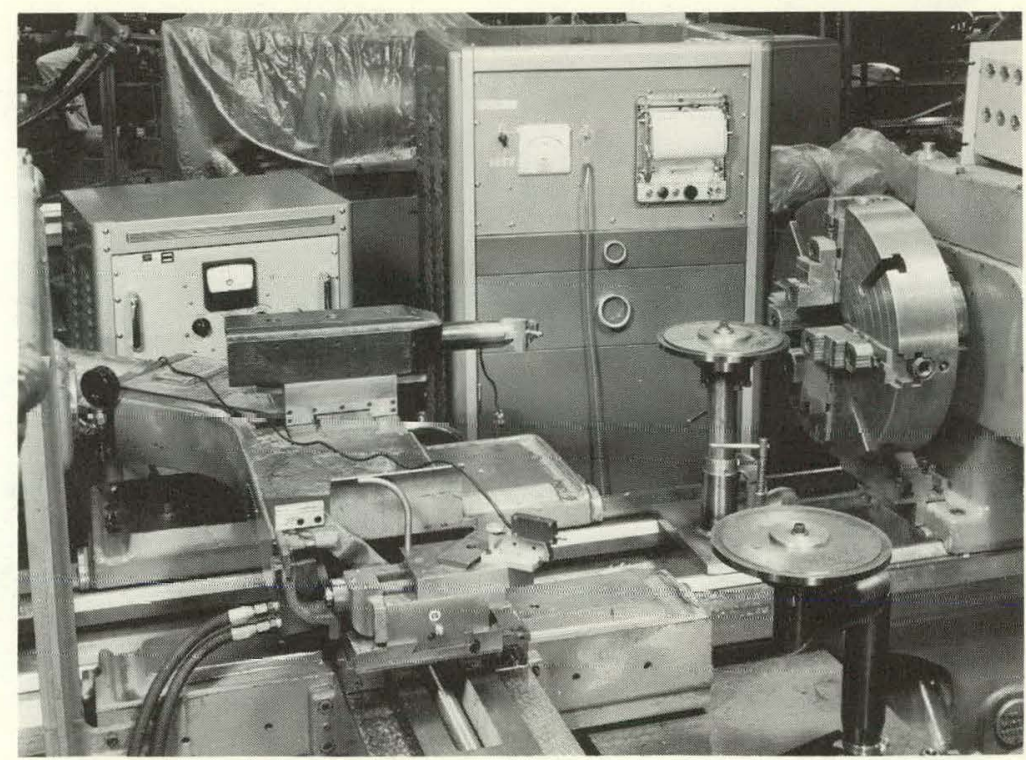

$109327(U)$

Figure 13. CIRCULAR TEMPLATES TO PERFORM TWIN-DISC CHECKS.

This test does not simulate actual machining conditions because such things as tool forces, tool wear, spindle growth, and spindle runout are eliminated.

On this machine, twin-disc checks were run for each of four systems according to the arrangements outlined in Table 1. Of the four systems, the system incorporating the hydrostatic slides with Bendix control was significantly better than the other three.

Table 1

COMPARISON OF TOTAL INDICATOR READINGS IN TWIN-DISC CHECKS ON VARIOUS CONTROL AND SLIDE SYSTEMS

\begin{tabular}{|c|c|c|c|c|}
\hline Test & $\begin{array}{l}\text { Type of } \\
\text { Control }\end{array}$ & $\begin{array}{l}\text { Type of } \\
\text { Slide }\end{array}$ & $\begin{array}{l}\text { Mean of Four Total } \\
\text { Indicator Readings } \\
\pm \text { LE of the Mean } \\
\text { (microinches) }\end{array}$ & $\begin{array}{c}\text { Difference } \\
+ \text { LE of the Difference } \\
\text { (microinches) }\end{array}$ \\
\hline 1 & Hydraulic & Conventional & $400 \pm 26$ & \multirow{4}{*}{$\begin{array}{l}246 \pm 39^{(1)} \\
22 \pm 43\end{array}$} \\
\hline 2 & $\begin{array}{l}\text { Electronic } \\
\text { (Thompson } \\
\text { amplifier) }\end{array}$ & Conventional & $154 \pm 29$ & \\
\hline 3 & $\begin{array}{l}\text { Electrnnir. } \\
\text { (Thompson } \\
\text { amplifier) }\end{array}$ & Hydrostatic & $132 \pm 32$ & \\
\hline 4 & $\begin{array}{l}\text { Electronic } \\
\text { (Bendix } \\
\text { amplifier) }\end{array}$ & Hydrostatic & $88 \pm 10$ & \\
\hline
\end{tabular}

(1) Statislicully significant. 
Machining Tests

Two different types of test parts were machined. One part was a straight cylinder with steps of 25, 50, and 100 microinches, as shown in Figure 14. The purpose of this test part was to determine if any of the systems would respond to inputs of small magnitude. All systems responded to all of the steps and, as the graph in Figure 15 indicates, there was no significant difference between any of the systems.

Test hemispheres were also machined with all four systems. Figures 16 through 18 show the dimensions of the test part and the machine setup. Inspection results were inconclusive because of excessive variation in the size of the parts. Inspection of the part contour was also inconclusive due to the lack of a setup point in the axial direction.

\section{Control-System Tests}

Four different servo control systems were tested. Three of these were electrohydraulic and one was pure hydraulic. Figure 19 shows the arrangement of the components of a typical electrohydraulic system; Table 2 lists the components of the three systems which were tested.

Testing the various control systems consisted of a velocity-error test and frequencyresponse tests with step inputs and sinusoidal inputs.

\section{Velocity-Error Tests}

Velocity error is present to some extent in control systems of this type. In order for the hydraulic actuator on which the cutting tool is attached to move, an error signal must be detected by the sensing element which, in this case, is a linear variable differential transformer (LVDT). The linear velocity of the hydraulic actuator depends on the displacement of the sensing element. The error signal which is necessary to move the actuator at the required velocity is the velocity error. This required velocity depends on the template configuration and the velocities of the carriage and cross slide. If the controlled slide on a duplicator always moved at a constant velocity, velocity error would not be a problem. Since this is not the case, this error will be present in the machined part. When tracing a circular template on a typical machine with a spindle speed of $115 \mathrm{rpm}$ and a feed of 500 microinches per revolution, the velocity of the 45-degree slide varies from 0.8 inch per minute at the equator and pole to 0 at 45-degrees latitude (Figure 20). By knowing the velocity-error characteristics of a system (Figure 21), the actual part error resulting from the velocity error can be determined (Figure 22). This calculated part error was a maximum of 150 microinches for the hydraulic system and 30 microinches for the electrohydraulic system.

Although the electrohydraulic system has less velocity error than the hydraulic system, it also has certain disadvantages. Because of its increased gain, it is more 


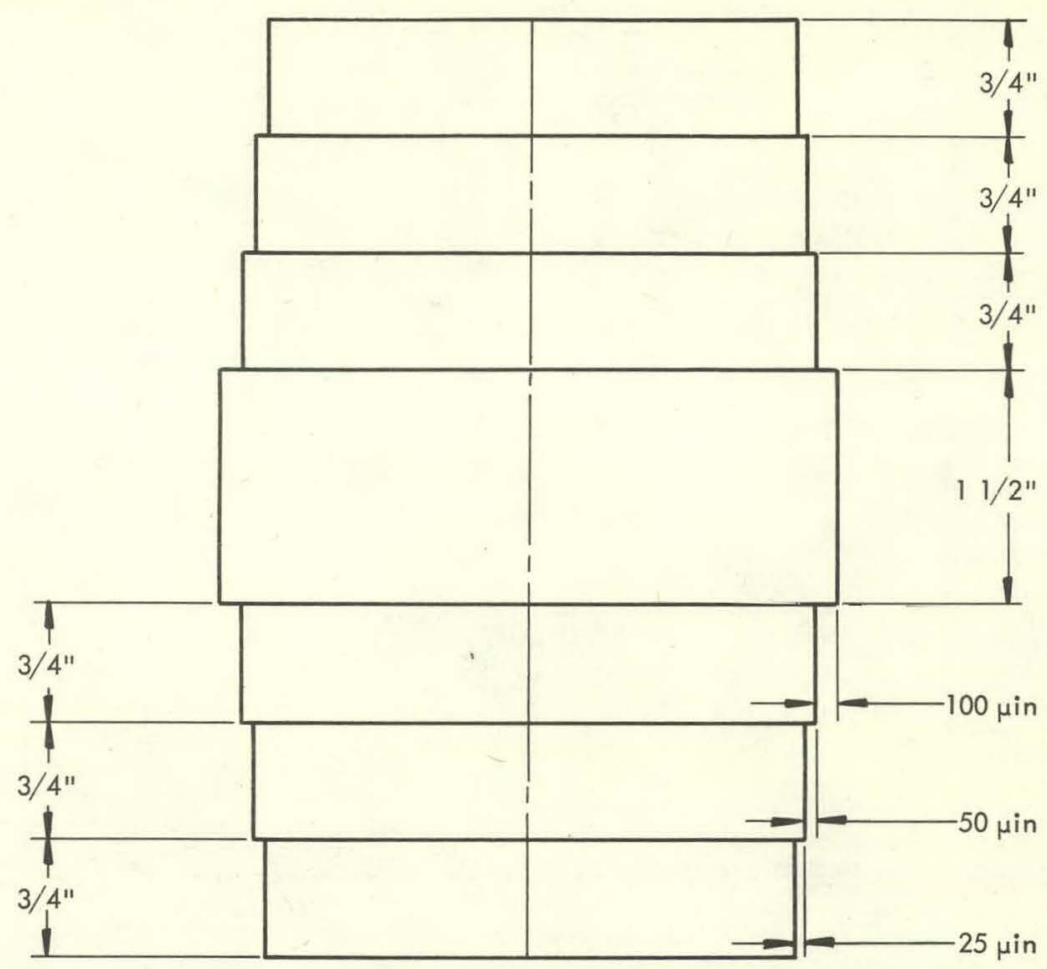

Figure 14. DIMENSIONS OF THE TEST CYLINDER.

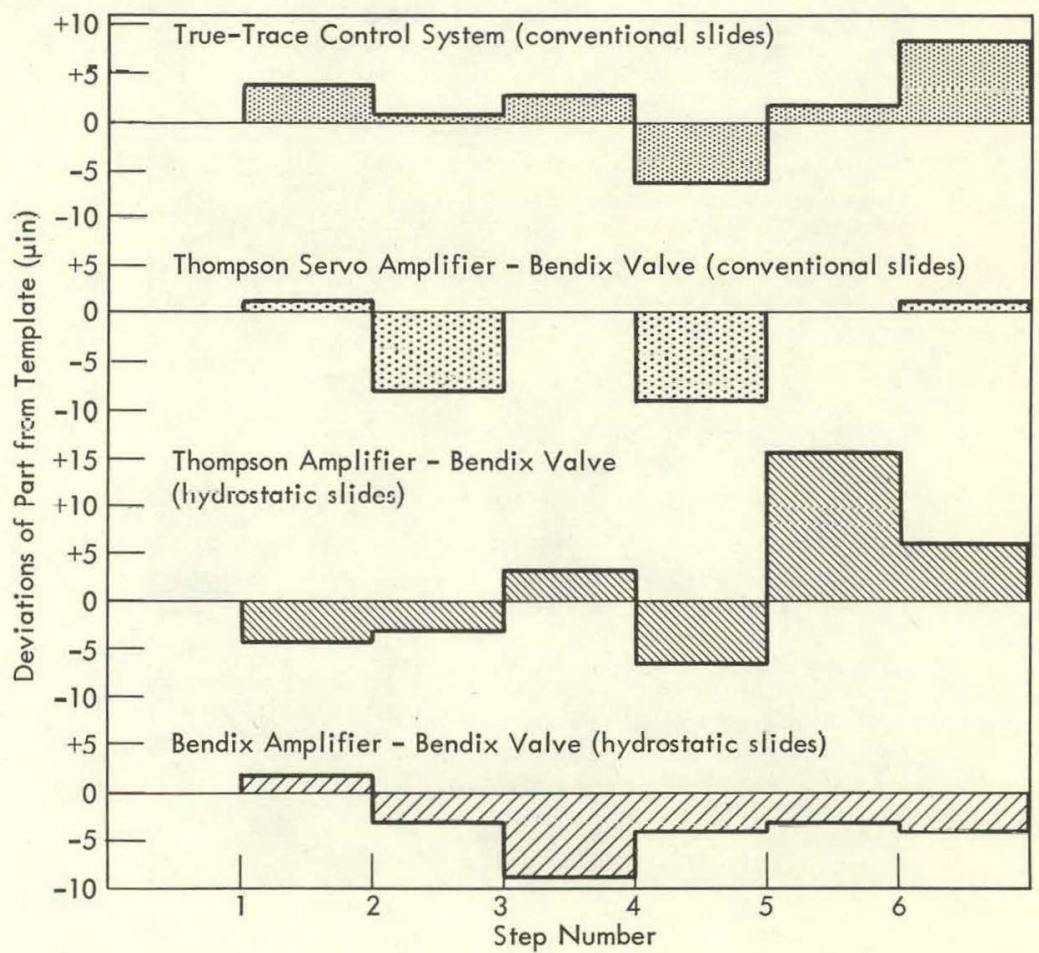

Figuie 15. RESULTS OF THF STEP-CYLINDER MACHINING TESTS. 


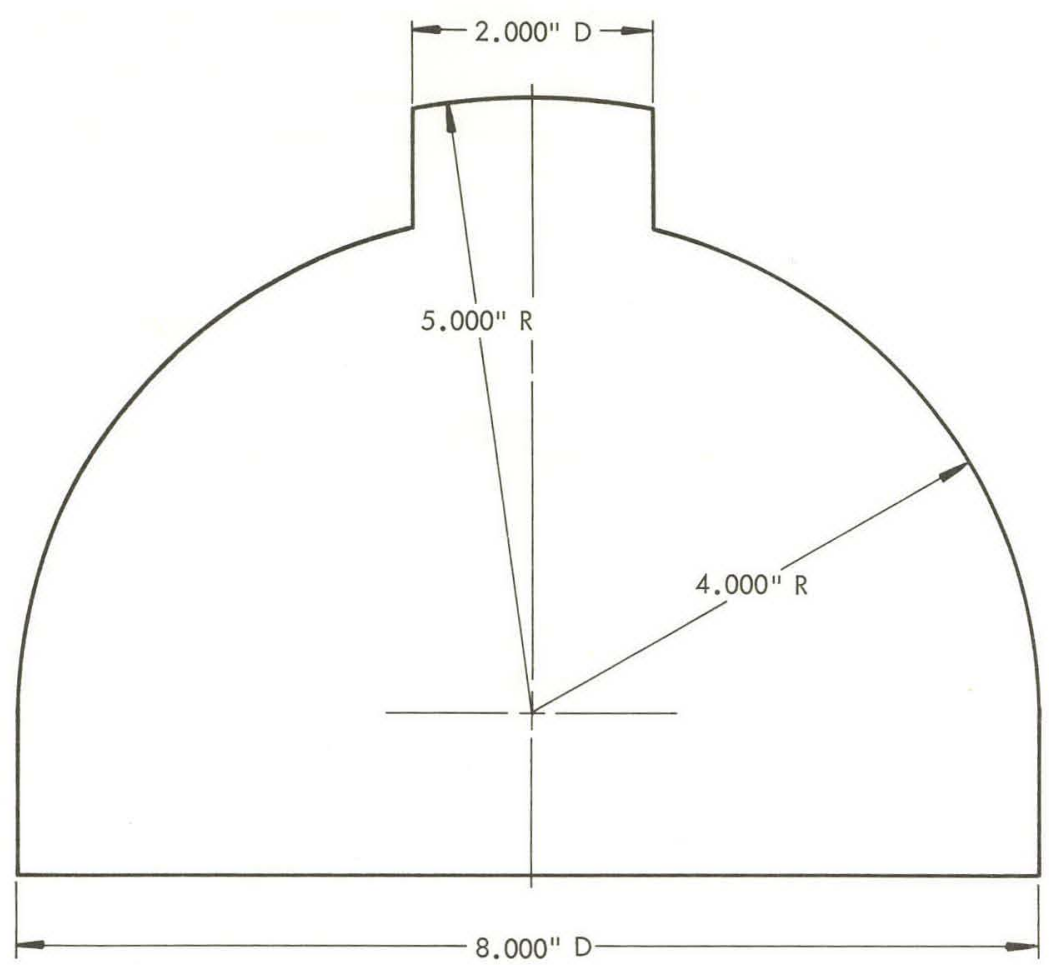

Figure 16. DIMENSIONS OF THE TEST PART.

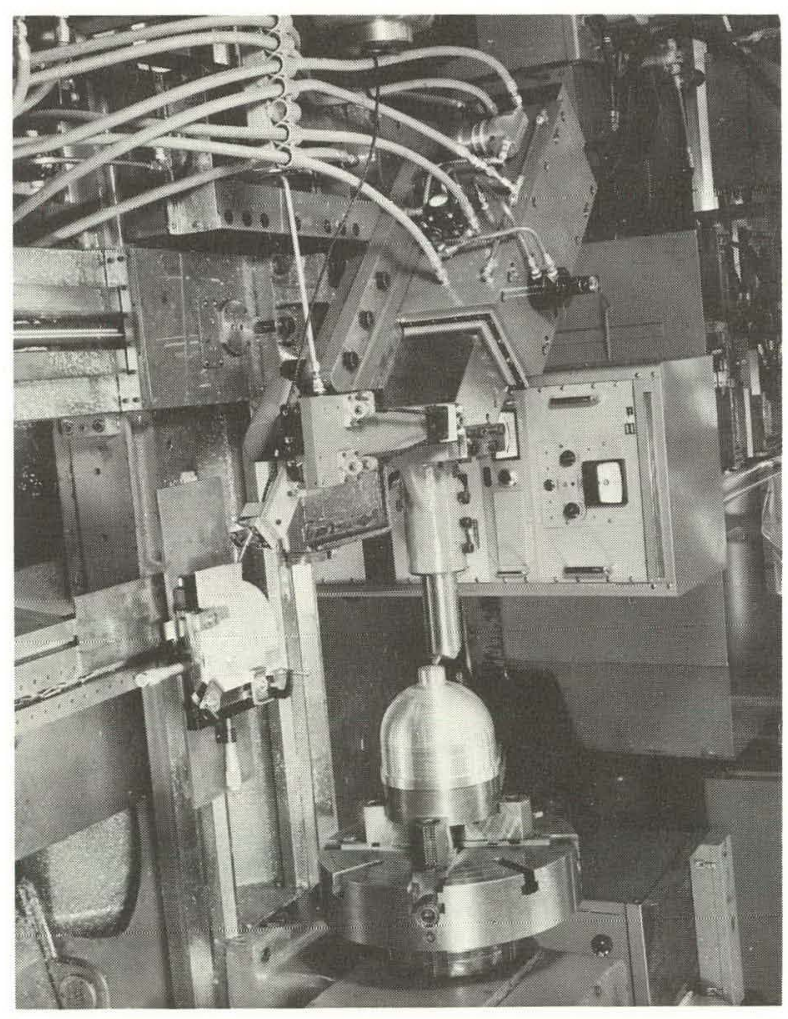

$109747(U)$

Figure 17. MACHINE SETUP FOR THE TEST HEMISPHERE. (Rear of Machine) 


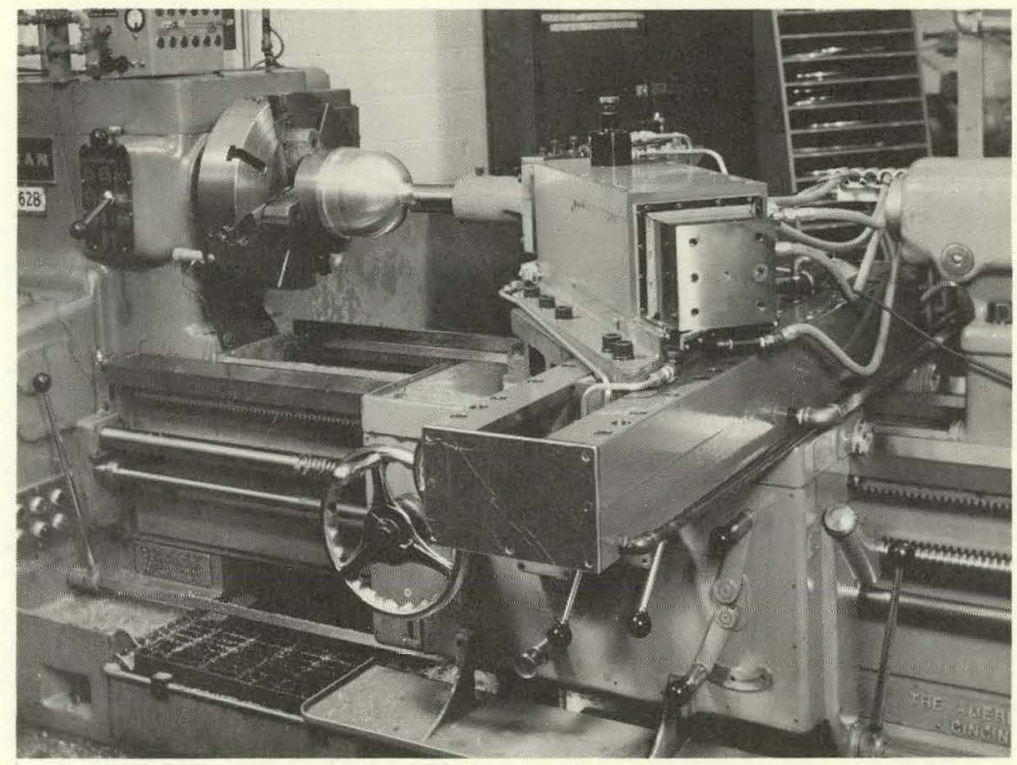

109745(U)

Figure 18. MACHINE SETUP FOR THE TEST HEMISPHERE. (Front of Machine)

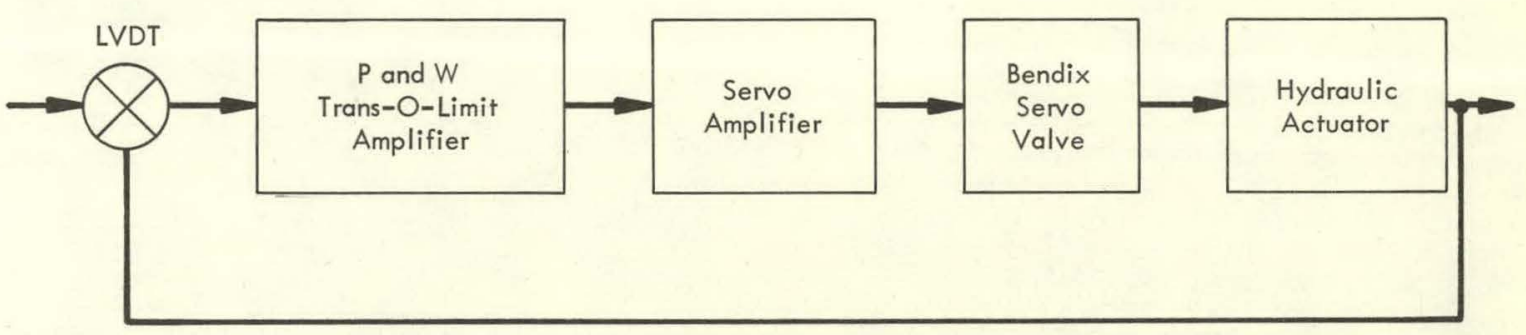

Figure 19. COMPONENTS OF THE ELECTROHYDRAULIC CONTROL SYSTEM.

sensitive to vibration and template roughness. Another disadvantage of this system is the large overshoot which occurs when the stylus contacts the template before each cut is made. Some overshoot is present in the hydraulic control, but it is very small compared to the electrohydraulic system. An indication of the relative overshoot of the two systems can be seen on the step input characteristics for an input of 150 microinches (Figures 23 and 24).

\section{Frequency-Response Tests}

Frequency-response tests using a sinusoidal input were conducted on both systems. Figures 25 and 26 show the results of the tests. These tests were conducted by applying a sinusoidal input to the stylus and measuring the output at the cutting tool 
Table 2

ELECTROHYDRAULIC CONTROL COMPONENTS

FOR THE THREE TEST SYSTEMS

System I

1. Linear Variable Differential Transformer

2. Modified Pratt and Whitney Trans-O-Limit Amplifier

3. Thompson Servo Amplifier

4. Bendix Servo Valve (6A1)

5. Conventional Slide

\section{System II}

1. Linear Variable Differential Transformer

2. Modified Pratt and Whitney Trans-O-Limit Amplifier

3. Thompson Servo Amplifier

4. Bendix Servo Valve (6A1)

5. Hydrostatic Bearing Slide

\section{System III}

1. Linear Variable Differential Transformer

2. Pratt and Whitney Trans-O-Limit Amplifier

3. Bendix Servo Amplifier

4. Bendix Servo Valve (6A2)

5. Hydrostatic Bearing Slide

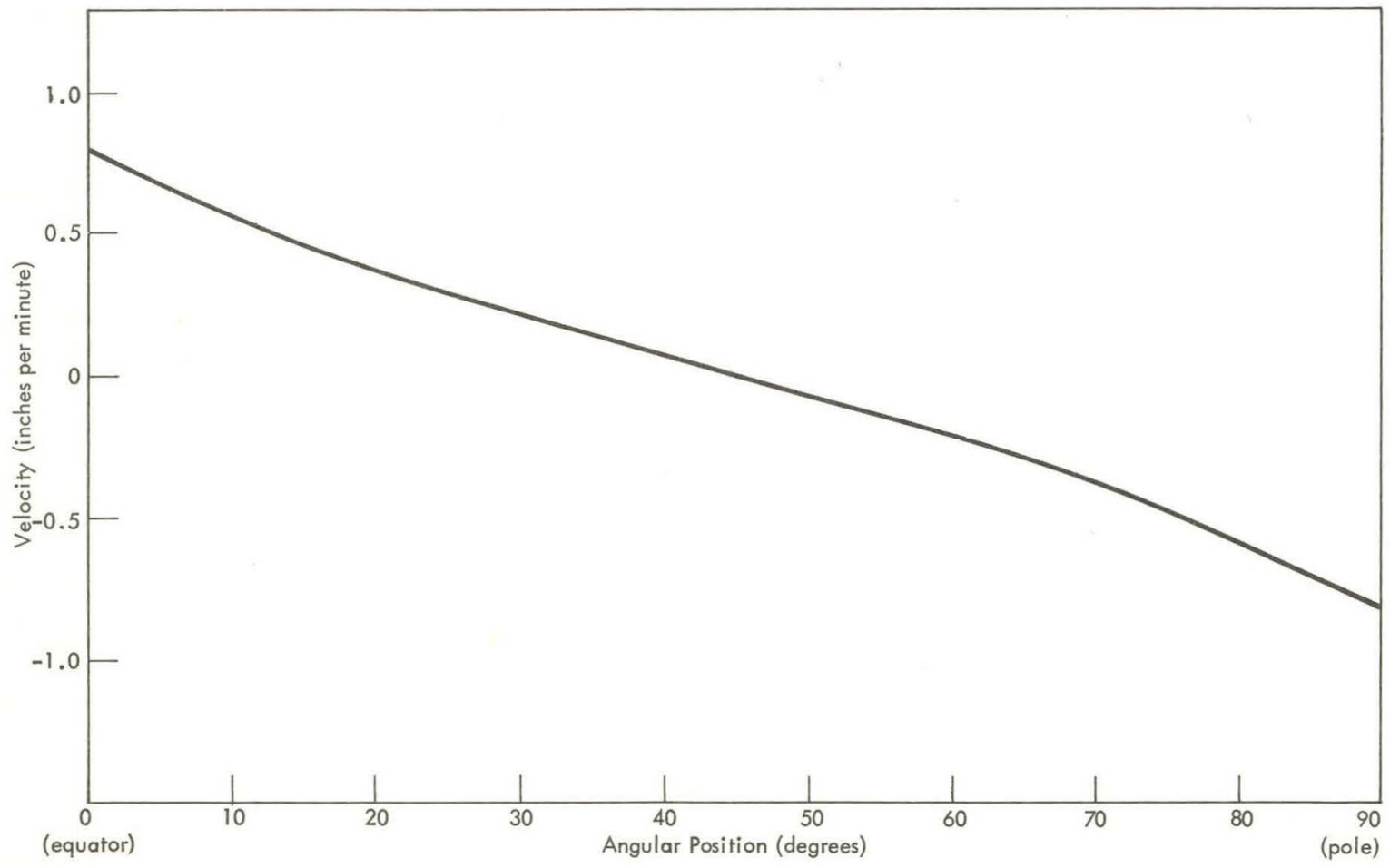

Figure 20. FORTY-FIVE-DEGREE SLIDE VELOCITY AS A FUNCTION OF THE ANGULAR POSITION ON THE TEMPLATE. (Spindle Speed - $115 \mathrm{rpm}$; Feed Rate $-5000 \mu \mathrm{in} / \mathrm{rev}$ ) 


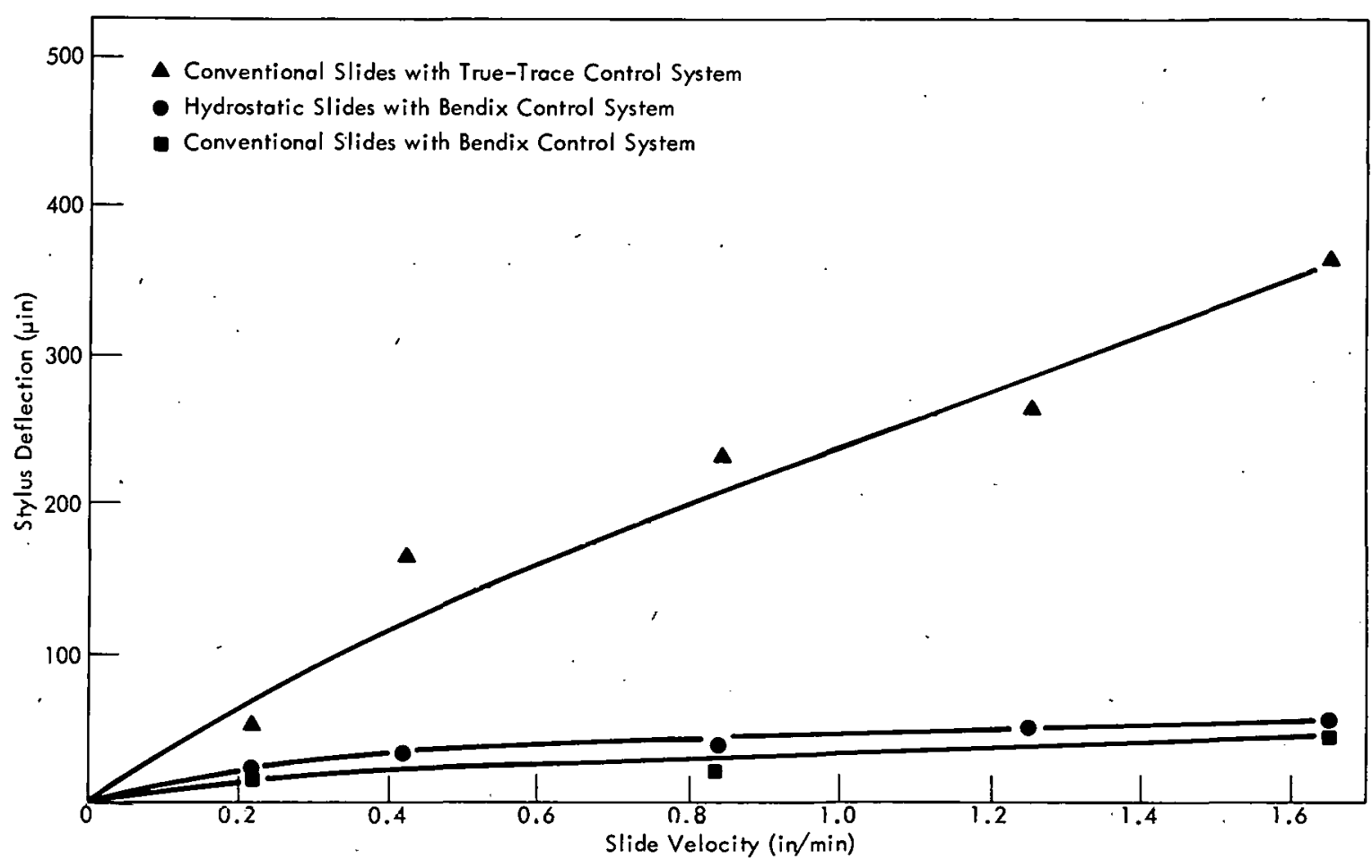

Figure 21. POSITION ERROR AS A FUNCTION OF THE SLIDE VELOCITY.

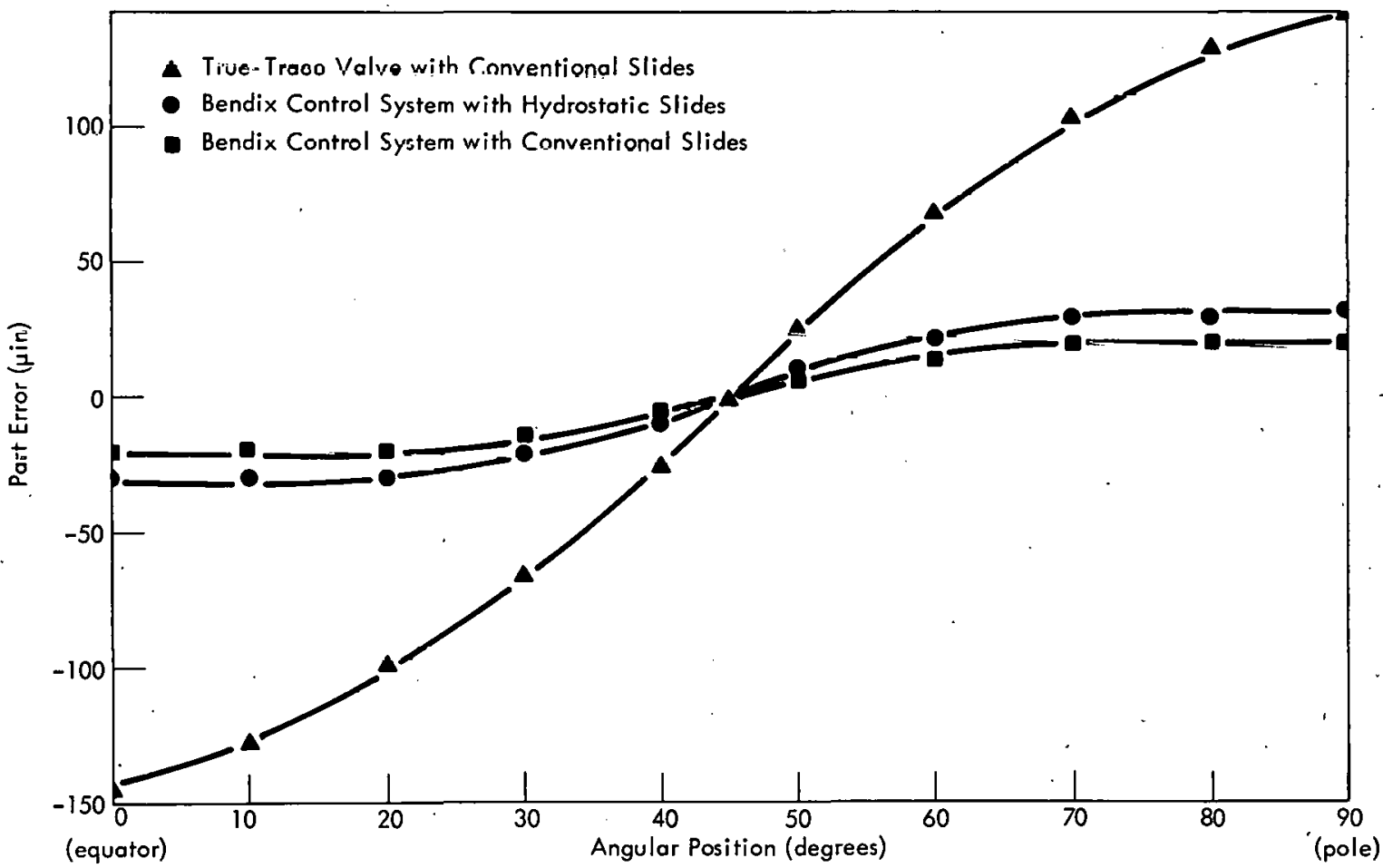

PIgure 22. PART ERROR DUE TU THE VELOCITY ERROR IN THE CONTROL SYSTEMS. 


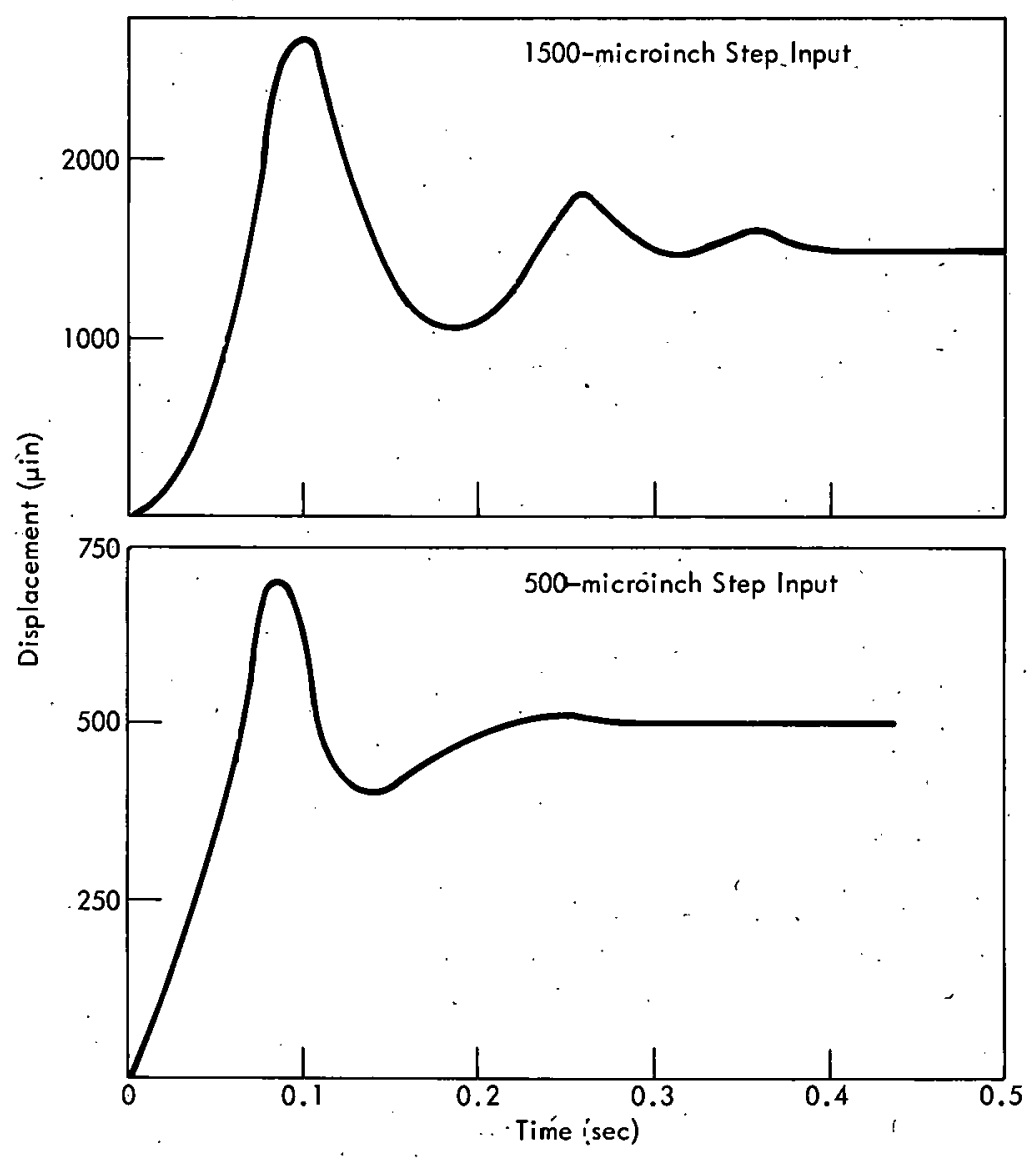

Figure 23. RESPONSE TO THE STEP INPUT FOR THE HYDROSTATIC SLIDE WITH A BENDIX CONTROL SYSTEM.

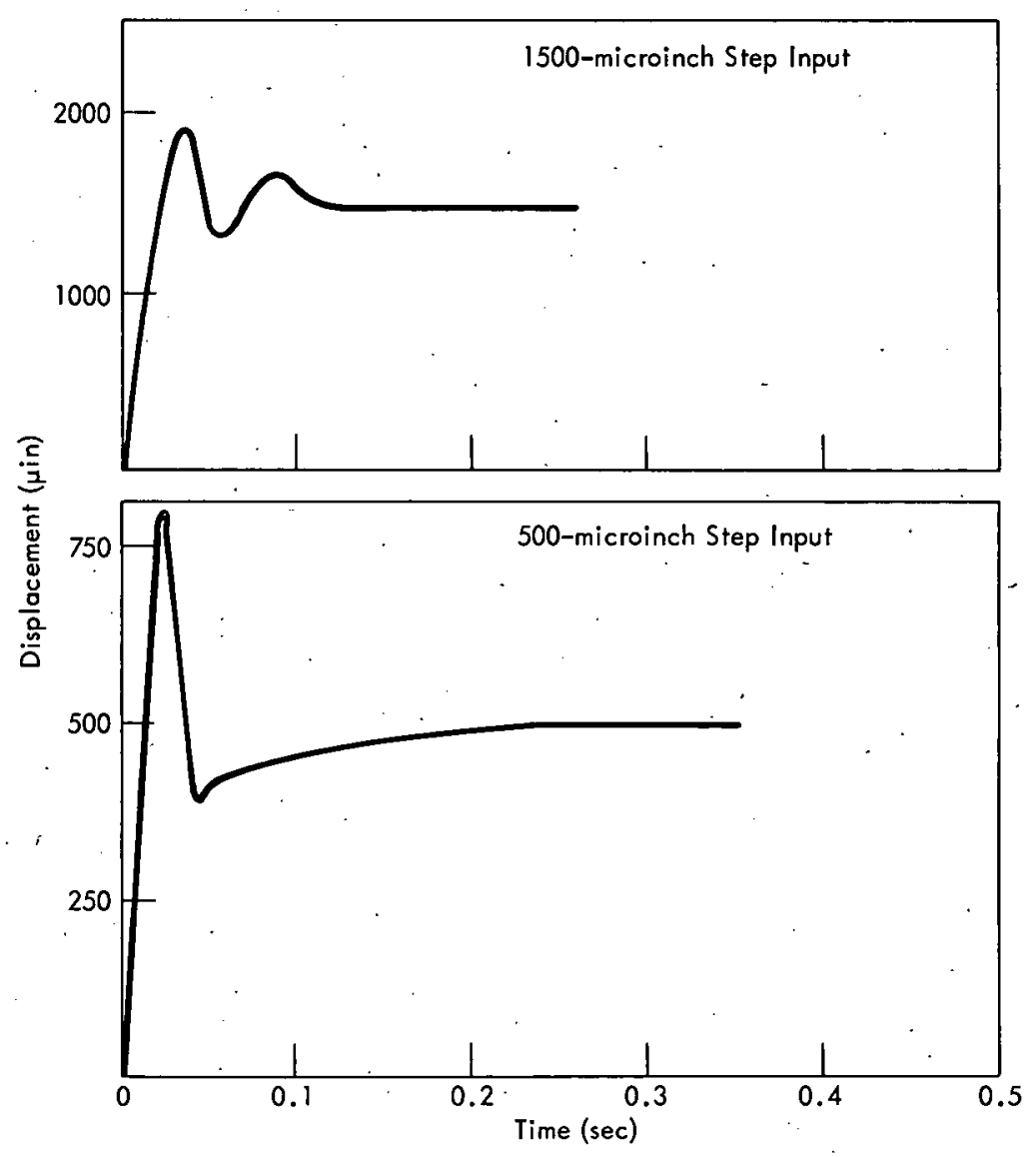

Figure 24. RESPONSE TO THE STEP INPUT FOR THE CONVEN. TIONAL SLIDE WITH A TRUE.TRACE CONTROL SYSTEM. 


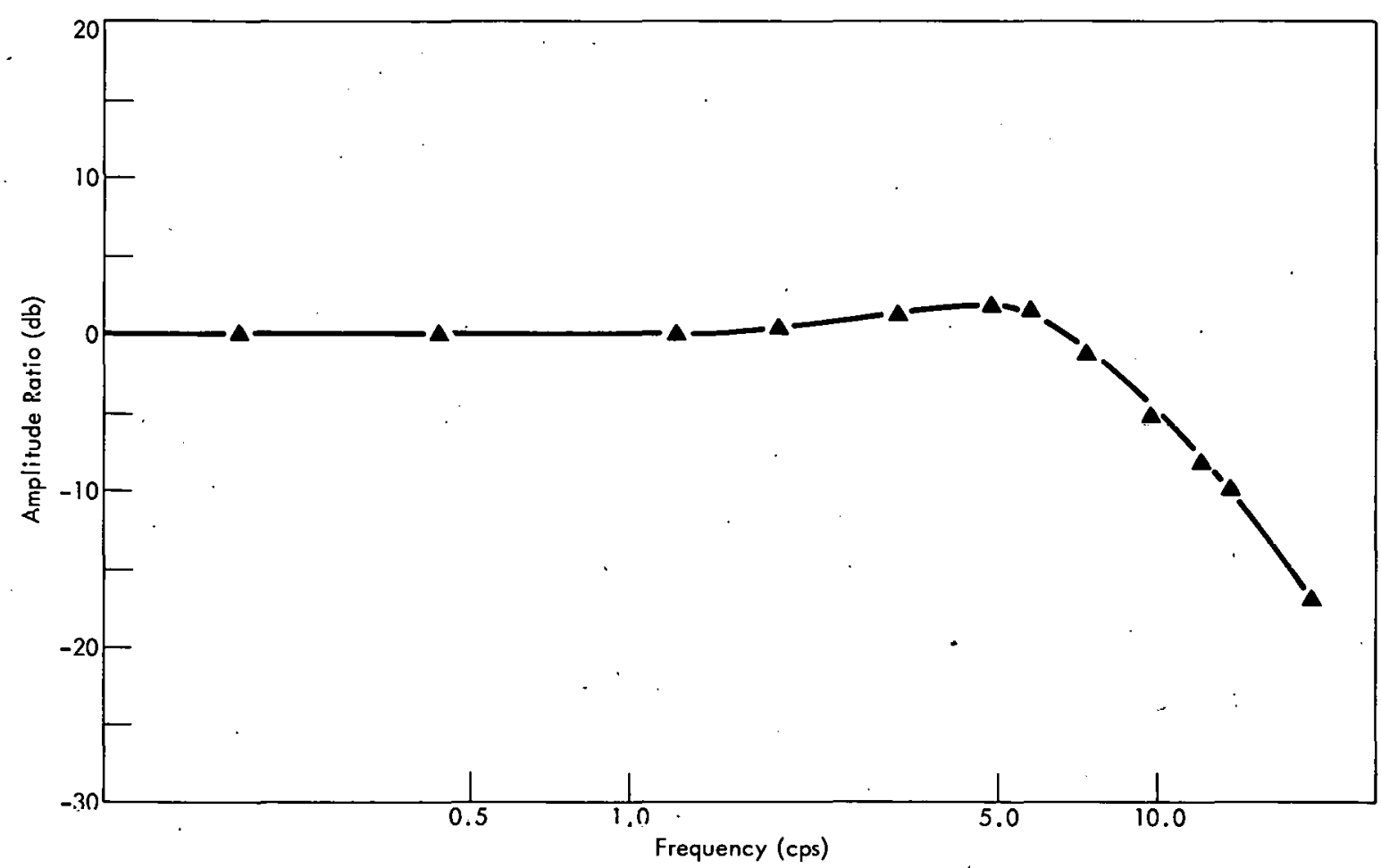

Figure 25. AMPLITUDE RATIO AS A FUNCTION OF THE FREQUENCY. (Hydrostatic Slides with Bendix Control System)

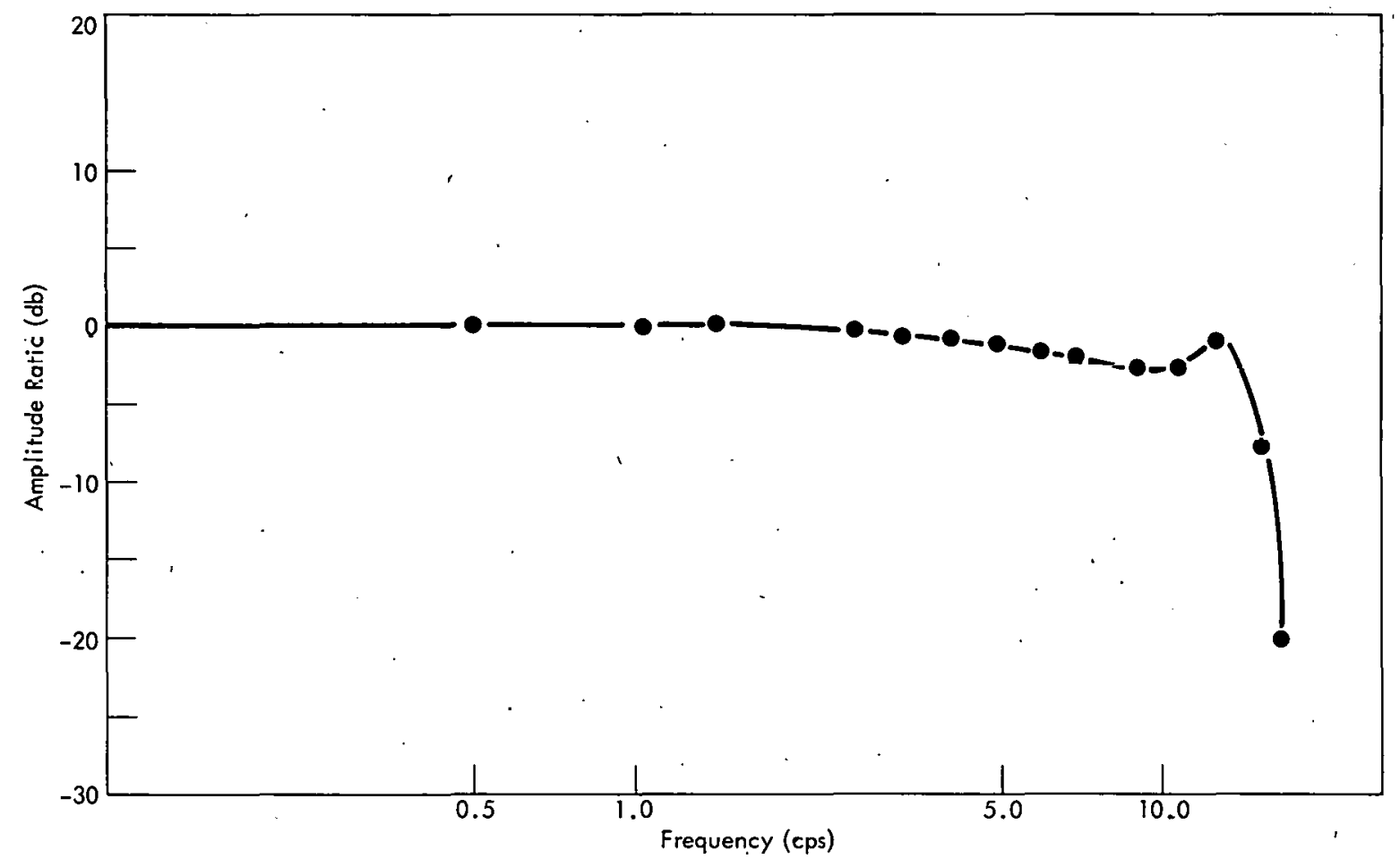

Figure 26. AMPLITURE RATIO AS A FUNCTIION OF THE FREQUENCY. (Conventional Slides with TrueTrace Control System) 
at different frequencies. By comparing the amplitude of the input to the amplitude of the output, the frequency response can be obtained. This test evaluates the performance of both the slide and the control system.

The frequency response of the hydraulic system was within $\pm 5 \mathrm{db}$ up to $15 \mathrm{cps}$, while the electrohydraulic system with the hydrostatic slides was good only to 10 cps within the same limits. The lower frequency response was probably due to internal leakage in the hydraulic actuator. By the nature of its construction there are no positive seals to prevent this leakage. 


\section{CONCLUSIONS}

No significant improvement in the machining accuracy of the machine was apparent from the installation of the hydrostatic bearing slides and the electrohydraulic control system. However, errors were apparent in the design of the hydrostatic bearing and it is possible that a better design would offer distinct improvements. A hydrostatic 45-degree slide with better stiffness and better frequency response characteristics would probably remove some of the sources of error in the machine, but other errors such as spindle growth, spindle runout, and template errors would have to be minimized before the value of the modifications could be determined.

Performance of the control system was not as good as expected. The velocity-error characteristics of the electrohydraulic system were much better than the hydraulic system, but the frequency response was slightly less than the hydraulic system.

Improved methods of evaluating the machining capabilities of lathes are needed.

Further work should be done to determine the benefits to be obtained with electrohydraulic control systems for duplicator lathes. The study of hydrostatic slides should continue, but not, for the moment, in conjunction with American duplicator lathes. In addition, improved methods of machine tool evaluation should be evolved. 